\title{
PELAYANAN PENYEBARAN INJIL BERDASARKAN 2 KORINTUS 6:1-10
}

\author{
David Susilo Pranoto
}

davidsusilopranoto@sttab.ac.id

\begin{abstract}
This 2nd Corinthian letter, written by the Apostle Paul, was addressed to the Corinthians. This letter is intended for the purpose, so that in conveying the gospel has the correct method so that the gospel can be accepted. The duty of believers is to convey the gospel / good news to everyone who does not know Christ. In writing this article we will explore how the Apostle Paul's perspective on the ministry of spreading the gospel based on 2 Corinthians 6: 1-10. Therefore through this writing, we will again remind and refresh believers about the importance of the ministry of spreading the gospel.
\end{abstract}

Keywords: Ministry, Spreading the Gospel.

Abstraksi: $\quad$ Surat 2 Korintus ini, ditulis oleh Rasul Paulus yang ditujukan kepada jemaat di Korintus. Surat ini ditujukan dengan tujuan, agar dalam menyampaikan Injil memiliki metode yang benar sehingga Injil tersebut bisa diterima. Tugas orang percaya adalah menyampaikan Injil/kabar baik kepada setiap orang yang belum mengenal Kristus. Dalam penulisan artikel ini akan menggali bagaimana perspektif Rasul Paulus tentang pelayanan penyebaran Injil berdasarkan 2 Korintus 6:1-10. Oleh karena itu melalui tulisan ini akan kembali mengingatkan dan menyegarkan kembali orang percaya tentang pentingnya pelayanan penyebaran Injil.

Kata Kunci: Pelayanan, Penyebaran Injil.

\section{LATAR BELAKANG MASALAH}

Kata Injil adalah kata yang berasal dari Arab. Di dalam bahasa Yunani kata yang diterjemahkan dengan Injil adalah: "euanggelion," yang artinya kabar kegirangan. Adapun yang dimaksud dengan "kabar kegirangan" adalah berita keselamatan, bahwa Tuhan Allah menyelamatkan manusia dengan perantaraan karya penebusan Kristus. ${ }^{1}$ Kata Injil, artinya "kabar baik" atau berita yang menggembirakan. ${ }^{2}$ Injil adalah berita sukacita tentang kerajaan Allah (penguasaan Allah), di mana di dalam tugas pemberitaan Injil, sasarannya ialah penguasaan Allah atas segala bangsa (bd. Matius 28:19-20; Markus 16:15). Pemberitaan Injil membawa kerajaan Allah ke Ujung Bumi (The End of The Word) dan di mana Kerajaan Allah berkuasa, di situ kejahatan ditahan sampai kedatangan Tuhan Yesus (bd. II Tesalonika 2:1-12). ${ }^{3}$

Pekabaran Injil dapat didefinisikan sebagai pemberitaan kabar gembira tentang pekerjaan Kristus. Dalam arti luas seluruh pekerjaan Gereja termasuk pekerjaan sosial merupakan pekabaran Injil. Pelayanan Gereja dalam masyarakat adalah salah satu cara

\footnotetext{
${ }^{1}$ Harun Hadiwijono, Kebatinan Dan Injil (Jakarta: BPK Gunung Mulia, 2006), 5.

${ }^{2}$ B. J. Boland, Intisari Iman Kristen (Jakarta:BPK Gunung Mulia, 1992), 67.

${ }^{3}$ Yakob Tomatala, Penginjilan Masa Kini (Malang:Gandum Mas, 2002), 35.
} 
untuk menyatakan kasih Tuhan. ${ }^{4}$ Injil adalah kabar tentang peristiwa-peristiwa yang menggembirakan, atau kabar sukacita. Kata Injil di gunakan oleh Yesus ketika ia memproklamasikan kedatangan kerajaan Allah (Mrk. 1:15) dan oleh Paulus untuk karya Allah yang telah dikerjakan melalui Yesus Kristus (Rm. 1:1-2). ${ }^{5}$

Injil adalah kabar baik atau kabar gembira berupa keselamatan, Tuhan menyelamatkan manusia lewat karya penebusan dari Kristus. Allah telah memilih kaum minoritas untuk menerima anugerah khusus ini, dan mempercayakan kepada mereka tugas membagikan Injil anugerah kepada bangsa-bangsa lain. Jadi, Paulus menyebarkan Injil kepada bangsa-bangsa bukan Yahudi dan mengaku bahwa anugerah ini diberikan kepada yang terkecil dari semua umat Allah, untuk mengajarkan kepada bangsa-bangsa bukan Yahudi dan untuk mengungkapkan Rencana Agung keselamatan Allah (Rm. 15:16; 1 Kor. 15:10; 2 Kor. 12:9; Gal. 1:15; Ef. 3:2, 7-9). Maksud pesan ini adalah bahwa tanpa anugerah Yesus, tidak ada seorang pun yang bisa menyebarkan Injil kepada bangsa-bangsa bukan Yahudi. ${ }^{6}$ Pekabaran Injil adalah pemberitaan kabar gembira tentang Tuhan dengan maksud supaya orang yang mendengar berita itu mengambil keputusan untuk bertobat kepada Kristus. Pekabaran Injil ditujukan kepada orang yang bukan Kristen dan kepada segi-segi yang tidak Kristen dalam kehidupan orang-orang Kristen, dengan maksud supaya semua orang itu menyerahkan kehidupannya secara penuh kepada Tuhan. ${ }^{7}$

Memberitakan Injil adalah perintah Tuhan Yesus. Tetapi dalam memberitakan Kabar Anugerah, tidak harus hanya ditujukan terhadap orang yang bukan Kristen saja; tetapi juga terhadap orang Kristen KTP (Kristen Tanpa Pertobatan), atau mereka sekedar beragama Kristen karena faktor keluarga, namun mereka belum mengenal Yesus Kristus dan anugerah-Nya secara pribadi dan benar (band. Yoh.3:3-7). ${ }^{8}$ Berdasarkan paparan diatas penulis menjelaskan bahwa memberitakan Injil adalah kabar anugerah yang diberikan kepada orang percaya untuk menyampaikan Injil yang sebenarnya. Kristus sendiri yang mengutus dan tiap-tiap orang Kristen diutus untuk memberitakan Injil kepada orang yang belum mengenal Kristus. Pekabaran Injil itu pertama-tama ditujukan kepada keluarga sendiri. Tujuan pekabaran Injil adalah supaya orang memuliakan dan menghormati akan Allah. Perintah pekabaran Injil adalah perintah Tuhan Yesus kepada

\footnotetext{
${ }^{4}$ Malcolm Brownlee, Tugas Manusia Dalam Dunia Milik Tuhan (Jakarta: BPK BPK Gunung Mulia, 2004), 29.

${ }^{5}$ W. R. F. Browning, Kamus Alkitab (Jakarta: BPK BPK Gunung Mulia, 2011), 152.

${ }^{6}$ Thomas Hwang, Apa Tujuan Dari Penciptaan (Korea:Sarah Hae-Ok Cho, 2016), 121.

${ }^{7}$ Malcolm Brownlee, Tugas Manusia Dalam Dunia Miliki Tuhan (Jakarta:BPK Gunung Mulia, 2004), 29

${ }^{8}$ Karel Sosipater, Etika Pelayanan (Jakarta:Suara Harapan Bangsa, 2010), 72.
} 
rasul-rasul berdasarkan Matius 28:18-20. Amanat ini kemudian harus diteruskan kepada Gereja Tuhan. ${ }^{9}$

Dalam Amanat Agung juga terdapat wewenang, perintah dan janji. Perintah Tuhan Yesus ini menuntut ketaatan dari setiap orang percaya. Selain ketaatan ada tugas utama dari perintah Amanat Agung yaitu: pergi kepada segala bangsa untuk memberitakan Injil dan menjadikan mereka murid Tuhan Yesus. Di dalam melaksanakan Amanat Agung ada suatu jaminan yang pasti yaitu: jaminan berkat dan jaminan keberhasilan bagi tugas penginjilan. Isi jaminan itu ialah penyertaan Tuhan Yesus (Matius 28:20). ${ }^{10}$

Ketika Tuhan Yesus naik ke surga, para murid diperintahkan supaya memberitakan Injil keselamatan keseluruh dunia. Pada mulanya Tuhan Yesus mempersiapkan 12 orang murid. Namun, seorang yang bernama Yudas Iskariot berkhianat. Ia di ganti oleh Matias. Walaupun Kristus tidak lagi hadir secara jasmani menyertai para murid-Nya, tetapi RohNya tetap menyertai mereka dalam pemberitaan Injil. "Aku menyertai kamu sehingga kesudahan alam," demikianlah firman Tuhan Yesus kepada murid-murid-Nya. ${ }^{11}$ Paulus juga begitu. Malah lebih tegas lagi. Memberitakan Injil Paulus adalah "keharusan" karena itu "celakalah aku, jika aku tidak memberitakan Injil" (1 Kor. 9:16). ${ }^{12}$

Oleh karena syarat mutlak untuk melihat kerajaan sorga adalah "dilahirkan kembali," maka merupakan kewajiban orang yang sudah lahir baru untuk memberitakan Injil tidak dapat dilakukan secara sembunyi-sembunyi atau terselubung. Yesus sendiri berpesan, "Apa yang kukatakan kepadamu dalam gelap, katakanlah itu dalam terang, dan apa yang dibisikan ke telingamu, beritakanlah itu dari atas atap rumah" (Matius 10:27). ${ }^{13}$

Pemberita Injil adalah sama, yaitu membawa orang-orang kepada suatu penyerahan kepada Yesus Kristus dan kepada suatu komitmen kepada satu sama lain dalam Tubuh Kristus. ${ }^{14}$ Injil adalah berita kesukaan, kabar gembira. Orang-orang yang terbesar karena penderitaan itu tidak mengeluh atau terlarut dalam kedukaan yang dalam. Sebaliknya, dengan kuasa Roh kudus mereka sanggup dimampukan menjadi saksi-saksi-Nya bagi banyak orang di Yudea dan Samaria. Injil yang penuh kesukaan membuat mereka mampu menghadapi tantangan pada saat itu dan tetap teguh bersaksi. Lihatlah akibat yang

\footnotetext{
${ }^{9}$ F. D. Wellem, Injil Dan Marapu (Jakarta:BPK Gunung Mulia, 2004), 254.

${ }^{10}$ Darsono Ambarita, Perspektif Misi Dalam Perjanjian Lama dan Perjanjian Baru (Medan:Pelita Kebenaran, 2018), 1.

${ }^{11}$ F. D. Wellem, Hidup Bagi Kristus (Jakarta:BPK Gunung Mulia, 2005), 3.

${ }^{12}$ Eka Darmaputera, Menyembah Dalam Roh dan Kebenaran (Jakarta:BPK Gunung Mulia, 2010), 108.

${ }^{13}$ E. B. Surbakti, Benarkah Injil Kabar Baik (Jakarta:BPK Gunung Mulia, 2008), 84.

${ }^{14}$ C. Peter Wagner, Manfaat Karunia Roh Untuk Pertumbuhan Gereja (Malang:Gandum Mas, 1991), 176.
} 
ditimbulkan dari pemberitaan Injil di Samaria. Ada sukacita yang sangat besar di kota itu (KPR 8:8). Karena Injil adalah kabar kesukaan maka tidak mungkin Injil diberitakan dalam kesedihan dan sungut-sungut. Dalam penganiayaan yang hebat itu, orang-orang percaya tidak meratapi penderitaannya. Mereka tetap bersukacita karena keselamatan yang dari Tuhan sehingga mereka dapat memberitakan Injil dengan penuh sukacita. Rasul Paulus adalah contoh yang amat baik sebagai penginjil. Perhatikanlah sikapnya terhadap jemaat Korintus. Sewaktu ia memberitakan Injil yang diutamakannya hanyalah inti yang penting, yaitu Yesus dan salibnya (1 Kor 2:1-5). ${ }^{15}$

Pekabaran Injil adalah pemberitaan kabar gembira tentang Tuhan dengan maksud supaya orang mendengar berita itu mengambil keputusan untuk bertobat kepada Kristus. pekabaran Injil ditujukan kepada orang-orang yang bukan Kristen dan kepada segi-segi yang tidak Kristen dalam kehidupan orang-orang Kristen, dengan maksud supaya semua orang itu menyerahkan kehidupannya secara penuh kepada Tuhan. ${ }^{16}$ Dalam buku Paulus Daun:

J.I.Packer berpendapat bahwa berdasarkan Perjanjian Baru, penginjilan adalah mengabarkan Injil. Ini adalah pekerjaan penyampaian; dalam hal ini Tuhan Yesus sebagai corong Allah untuk menyampaikan karunia Allah kepada manusia yang berdosa dalam kenyataan apakah kamu sudah mengabarkan Injil, ini bukan terletak akibat kesaksian sehingga orang bertobat, tetapi terletak kamu apakah kamu dengan ketulusan menyampaikan kabar Injil tersebut. ${ }^{17}$

Penginjil adalah orang yang diberi karunia khusus dari Roh kudus untuk memberitakan kabar baik. Metode-metode yang dipakai akan berbeda-beda. Hal itu bergantung pada kesempatan dan panggilan yang dimiliki setiap penginjil. Namun, ada satu hal pokok yang sama: seorang penginjil di panggil dan diperlengkapi secara khusus oleh Tuhan untuk memberitakan Injil kepada orang-orang yang belum percaya kepada Kristus. ${ }^{18}$ Orang yang dipenuhi Roh Kudus adalah orang yang mementingkan Injil dan pengabarannya, karena itulah Roh Kudus diturunkan ke dunia. Roh Kudus diberikan untuk memuliakan Kristus. ${ }^{19}$ Karena memberitakan Injil adalah hal yang sudah Allah tetapkan dalam kekekalan dan dipercayakan kepada kita untuk melaksanakannya, maka orang-

\footnotetext{
${ }^{15}$ W. Stanley Heath, Penginjilan dan Pelayanan Pribadi (Surabaya: YAKIN, 1966), 18.

${ }^{16}$ Malcolm Brownlee, Tugas Manusia Dalam Dunia Milik Tuhan (Jakarta: BPK Gunung Mulia, 2011), 29. 2015), 159

${ }^{17}$ Paulus Daun, Misiologi Dalam Perspektif Historikal \& Doktrinal (Jakarta: Serving In Mission,

${ }^{18}$ Billy Graham, Beritakan Injil (Bandung: Lembaga Literatur Baptis, 1992), 14-15.

${ }^{19}$ Stephen Tong, Roh Kudus Doa dan Kebangunan (Surabaya: Momentum, 2004), 104.
} 
orang yang dipredestinasikan oleh Allah akan menerima Injil dan menjadi anak-anak Allah Jika kita sungguh-sungguh tahu bahwa penginjilan adalah menjalankan kehendak Allah. ${ }^{20}$

\section{METODE PENELITIAN}

Dalam penelitian ini, penulis menggali apa teologi "Perpektif Rasul Paulus tentang pelayanan penyebaran Injil" berdasarkan 2 Korintus 6:1-10 yang akan dibangun oleh Rasul Paulus. Metode Deskriptif adalah suatu metode dalam peneliti status sekelompok manusia, suatu objek, suatu set kondisi, suatu sistem pemikiran ataupun suatu kelas peristiwa pada masa sekarang. ${ }^{21}$ Penulis juga menganalisa tulisan-tulisan para theolog dalam mencermati perspektif Rasul Paulus tentang pelayanan penyebaran Injil dan membuat kajian eksegetikalnya. Metode analisis adalah suatu proses penelitian untuk menyelidiki suatu peristiwa dan untuk mengetahui keadaan sebenarnya serta memberi gambaran kebenaran sesuai dengan data yang ada. ${ }^{22}$

\section{LATAR BELAKANG 2 KORINTUS 6:1-10}

Rasul Paulus sangat kuatir tentang penerimaan suratnya yang pertama dari jemaat di Korintus, surat mana berisi nasihat dan teguran yang berbeda tegas dan keras. Ia semakin gelisah secara badani maupun rohani (1:3-11), oleh karena segala penderitaan yang dialaminya dalam pelayanan. Untuk mengetahui reaksi jemaat di Korintus terhadap suratnya yang pertama, Paulus mengutus Titus. Mungkin juga Timotius, sebagai wakilnya untuk bertemu dengan jemaat, supaya dapat diperkirakan manfaatnya atas menerimaan Surat I Korintus itu waktu Paulus ada dalam perjalanan pekabaran Injil yang ketiga. Ketika ia di Filipi, Titus membawa berita dari Korintus. ${ }^{23}$

Selama Paulus tinggal di Efesus ia tetap memelihara hubungan dengan jemaatjemaat di Akhaya yang dibangunnya pada perjalanan sebelumnya. Gereja di Korintus merupakan suatu masalah yang merepotkan dirinya karena ketidakstabilannya. Karena sebagian terbesar dari anggota jemaat adalah bukan orang Yahudi yang belum pernah dididik dalam Kitab Suci Perjanjian Lama, dan yang latar belakang religius serta moralnya sangat bertolak belakang dengan norma-norma kristiani, banyak hal yang harus diajarkan kepada mereka sebelum mereka mencapai kedewasaan rohani (I Korintus 3:1-3). ${ }^{24}$

\footnotetext{
${ }^{20}$ Stephen Tong, Theologi Penginjilan (Surabaya: Momentum, 2013), 52.

${ }^{21}$ Moh Nazir, Metode Penelitian (Jakarta: Ghalia Indonesia, 1988), 63.

${ }_{22}$ Dean J. Champion, Metode dan Masalah Penelitian sosial (Bandung: Rafika Aditama, 1999), 6

${ }^{23}$ Adina Chapman, Pengantar Perjanjian Baru (Bandung: Kalam Hidup, 2014), 70.

${ }^{24}$ Merril C. Tenney, Survei Perjanjian Lama, (Malang: Gandum Mas, 2009) 365.
} 
Paulus menulis beberapa surat kepada jemaat di Korintus, termasuk surat sebelumnya yang disebutkan dalam 1Kor. 5:9 dan surat yang kita kenal sebagai 1Korintus. Ia juga menyebutkan sebuah surat yang ia tulis ketika ia sedang sedih (2 Kor. 2:3-4). Surat 2 Korintus ini sangat mungkin terdiri atas dua surat Paulus yang disebarkan terpisah namun akhirnya dijadikan satu. Yang pertama terdiri atas pasal 1-9 dan yang kedua berisi pasal 10-13. Mungkin 6:14-7:1 merupakan potongan dari suratnya yang lain, karena bagian ini memotong alur pemikiran dari 6:11-13 ke 7:2. Mungkin Paulus mula-mula tinggal di Korintus sekitar tahun 50-51 M, lalu ia menulis 1 Korintus sekitar tahun 53-54 M, setelah ia kembali dari Yerusalem (Kis. 18). Kedua surat yang digabungkan menjadi surat 2 Korintus ditulis beberapa waktu kemudian. ${ }^{25}$ Surat 2 Korintus adalah bagian dari surat menyurat Paulus dengan orang-orang Kristen di Korintus yang berhasil dilestarikan. Andaikan kita memiliki seluruh kumpulan surat menyurat, termasuk pesan-pesan yang dikirimkan kepada rasul dari Korintus, tentu kita akan lebih mampu memahami mengapa Paulus menulis seperti yang ia lakukan dalam suratnya tersebut. ${ }^{26}$

\section{Kota Korintus}

Kota Korintus adalah sebuah kota yang terkemuka di negara Yunani. Secara geografis, kota ini terletak di pertengahan segala arus perdagangan antara daerah-daerah timur dan barat. Bapa-bapa dari kota ini bangga atas kedudukannya, karena kekayaan dan keindahannya. Kota ini mula-mula dibangu pada tahun 146 s.M. ${ }^{27}$ Kota Korintus terletak di lokasi yang cukup menguntungkan. Kota ini tidak hanya di lalui oleh jalur utama yang menghubungkan wilayah Timur dan Barat, tetapi beberapa rute laut juga bertemu di kedua pelabuhannya. Hal ini membuat kota Korintus amat kaya, terpilih sebagai ibukota Provinsi Akhaya, dan menjadi tempat tinggal gubernur Romawi di provinsi itu. ${ }^{28}$

Korintus adalah sebuah kota pelabuhan yang sangat penting di Yunani Tengah, juga merupakan pusat kebudayaan dan agama. Kota itu penuh dengan penganut berbagai kepercayaan, antara lain persekutuan orang Yahudi yang cukup besar. Pada saat perjalanan misinya yang kedua, Paulus mendirikan jemaat di Korintus. Surat pertama kepada jemaat Korintus ditulis di Efesus (1 Kor. 16:8) tahun 55 M dalam perjalanan ketiganya. Pada masa itu muncul berbagai macam masalah di dalam jemaat di Korintus. Keadaan tegang dan perselisihan meningkat sehingga menyebabkan munculnya golongan-golongan. Surat

\footnotetext{
${ }^{25}$ Howard Clark Kee, Alkitab Edisi Studi, (Jakarta: Lembaga Alkitab Indonesia, 2011), 1890.

${ }^{26}$ V. C. Pfitzner, Ulasan Atas Surat 2 Korintus Kekuatan Dalam Kelemahan (Jakarta: BPK Gunung Mulia, 2008), 1.

27 Adina Chapman, Pengantar Perjanjian Baru (Bandung: Kalam Hidup, 2014), 63.

${ }^{28}$ Donald Guthrie, Pengantar Perjanjian Baru Volumen 2 (Surabaya: Momentum, 2009), 27.
} 
ini menjawab satu surat yang telah Paulus terima dari jemaat. Tepat satu tahun setelah surat yang pertama, ia menulis surat yang kedua, masih pada saat perjalanannya yang ketiga. Meskipun banyak hal yang terjadi, Paulus tetap mengunjungi jemaat di Korintus (2Kor. 2:1, 12:14). Titus memberikan berita yang positif kepada Paulus tentang perkembangan dan keadaan jemaat. 2 Korintus adalah sebuah surat yang bersifat sangat pribadi, yang di dalamnya Paulus memberikan perhatian lebih terhadap arti jabatannya sebagai rasul, dan relasinya dengan jemaat. Paulus juga menganjurkan pengumpulan dana untuk membantu jemaat di Yerusalem. ${ }^{29}$

\section{Penulis 2 Korintus}

Surat 1 Korintus mempunyai suatu garis pandangan yang jelas dari mula sampai akhir. Tetapi surat 2 Korintus sering kelihatan seperti bunga rampai dari nasihatnasihat Paulus tentang berbagai masalah. Beberapa ahli menduga surat ini merupakan kumpulan dari dua atau tiga surat yang mula-mula ditulis secara terpisah, dan pada kemudian hari digagung menjadi satu oleh seseorang penyunting. Ini merupakan prosedur yang lazim di dunia purba, dan pada prinsipnya siapa yang mengumpulkan surat-surat Paulus, akan menggabungkannya supaya cocok dengan panjang buku yang lazim. ${ }^{30}$ Setelah beberapa kali berhubungan dan surat-menyurat yang awal diantara Paulus dengan Jemaat itu misalnya: I Kor $1: 11 ; 5: 9 ; 7: 1)$, maka Paulus menulis surat 1 Korintus dari Efesus (awal tahun 55/56). Paulus menulis surat 2 Korintus dari Makedonia (akhir tahun $55 / 56) .^{31}$

Surat 2 Korintus ini mengenai kepentingan mayoritas jemaat yang setia dan soal sifat pelayanannya, pelayanan terhadap Pemberitaan Injil, pelayanan dalam kebenaran, dan pelayanan dalam penderitaan pribadi. Membicarakan tentang kemurahan hati Kristen dan pengumpulan uang bagi orang Kristen di Yerusalem yang memerlukan bantuan. Jawaban Paulus terhadap pertanyaan kepada sedikit jemaat yang melawan, soal sifat pengecut dan kelemahan. Juga disinggung mengenai kekuatirannya terhadap jemaat di Korintus, supaya memiliki ketetapan hati untuk bersikap teguh. ${ }^{32}$

\section{Waktu dan Tempat Penulisan}

Surat Korintus ditulis di Korintus (15:32), agaknya pada akhir perjalanan Paulus yang ketiga (15:25), menjelang awal musim pelayaran di Wilayah Laut Tengah, jadi pada akhir musim dingin (Februari-Maret 57). Keadaan Paulus pada saat itu di gambarkan

\footnotetext{
${ }^{29}$ Jasper Klapwijk, Perjanjian Baru (Jakarta: Yayasan Komunika Bina Kasih, 2015), 96

${ }^{30}$ John Drane, Memahami Perjanjian Baru (Jakarta: BPK Gunung Mulia, 2005), 3.

${ }^{31}$ Donald C. Stamps, Alkitab Penuntun (Malang: Gandum Mas, ) 1916.

${ }^{32}$ Karel Sosipater, Etika Perjanjian Baru, (Jakarta: Suara Harapan Bangsa, 2010), 401-402.
} 
dalam Kisah Para Rasul 20:2-3. Ternyata pada waktu itu orang-orang Yahudi bermaksud membunuh dia, sehingga ia terpaksa membatalkan pelayaran ke Siria dan mengambil jalan darat ke Filipi (700 km jalan kaki dari Korintus). ${ }^{33}$

Sejak awal, surat ini diterima sebagai surat yang ditulis oleh Paulus. Dalam 2 Korintus 12:14 dan 13:1, Paulus mengumumkan kunjungannya yang ketiga kepada jemaat di Korintus, sehingga mestinya ia sudah ke Korintus sekali lagi setelah menulis Surat 1 Korintu. Dalam 2 Korintus 1:15-16, Paulus berbicara tentang rencana perjalanan langsung ke Korintus dan dari sana ia ke Yudea. Sementara itu, menurut 2 Korintus 2:1, Paulus mengatakan bahwa ia telah memutuskan tidak akan melakukan lagi suatu perjalanan dalam dukacita. ${ }^{34}$ Surat ini ditulis pada saat perjalanan ketiga Paulus untuk memberitahukan Injil (tahun $57 \mathrm{M}$ )- beberapa bulan atau mungkin setahun atau lebih sesudah I Korintus. Surat ini ditulis dari Makedonia, mungkin dari Filipi. ${ }^{35}$ Paulus ini sudah tiba di Korintus setelah surat 1 Korintus. Mereka menyebut dirinya sebagai “pelayan Kristus” (2 Kor. 11:23), yakni orang-orang berfungsi dalam melayani meja dan memberitakan Injil serta menjadi "Rasul Kristus" 2 Kor. 11:13). ${ }^{36}$

\section{Tujuan Penulisan}

Setiap surat yang ditulis oleh Rasul Paulus mempunyai pokok utama. Setiap surat juga mempunyai tujuan. Tujuan-tujuan itu ialah hal-hal yang diharapkan oleh penulis surat itu supaya dilakukan oleh orang-orang yang membacanya. Dalam suratnya yang kedua kepada jemaat di Korintus, Rasul Paulus mempunyai dua tujuan. Ketika ia menulis Kitab 2 Korintus, Rasul Paulus ingin supaya mereka: Memperlakukan Injil sebagai sesuatu yang berharga. menerima dia sebagai rasul yang sejati. ${ }^{37}$ Tujuan itu dapat dicapai melalui Paulus yang hasilnya juga turut mewujudkan suatu keseimbangan antara orang-orang yang sungguh-sungguh jatuh miskin di Yerusalem dengan orang-orang yang tidak berada tetapi berkecukupan dalam jemaat-jemaat yang di kunjungi Paulus di Asia kecil dan wilayah Yunani (bnd. 2 Kor. 8:13-14). Sesuai perjalanan misinya yang ketiga. Paulus beserta dengan teman-temannya akan mengantarkan hasil sumbangan itu ke kota suci. ${ }^{38}$

\footnotetext{
${ }^{33}$ Th. Van Den End, Tafsiran Alkitab Surat Roma (Jakarta: BPK Gunung Mulia, 2008), 3.

${ }^{34}$ Samuel Benyamin Hakh, Perjanjian Baru: Sejarah, Pengantar Dan Pokok-Pokok Teologisnya, (Bandung: Bina Media Informasi, 2010), 155.

${ }^{35}$ Bible Institute, The Wycliffe Bible Commentary, (Malang: Gandum Mas, 2001), 661

${ }^{36}$ Hakh, Perjanjian Baru: Sejarah, Pengantar dan Pokok-pokok Teologisnya, 156.

${ }^{37}$ Ephraim Moalusi, Penyedilikan Perjanjian Baru (Bandung: Kalam Hidup, 1977), 95.

${ }^{38}$ Ulrich Beyer, Memberi Dengan Sukacita (Jakarta: BPK Gunung Mulia, 2008), 12.
} 


\section{KAJIAN EKSEGETIS 2 KORINTUS 6:1-10}

Rasul Paulus memiliki perspektif tersendiri tentang pelayanan penyebaran Injil. Ada beberapa perspektif Rasul Paulus tentang pelayanan Penyebaran Injil yaitu:

\section{Tidak Menyia-Nyiakan Kasih Karunia Allah (ayat 1)}

Kata dasar dari menyia-nyiakan adalah sia-sia dalam bahasa Yunani menggunakan

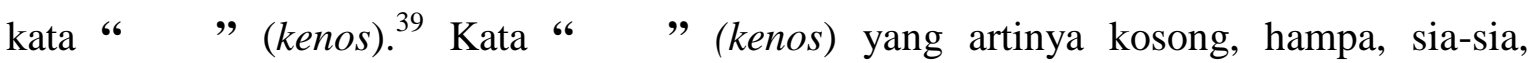
bodoh. $^{40}$ Dengan kasus adjective neuter singular accusative no degree. kasus ini menunjukkan bentuk kata sifat, yang bersifat netral, tidak ada derajat tingkat yang berbentuk tunggal. Dengan demikian kata sia-sia merupakan bentuk kata sifat yang diterjemahkan kosong, hampa, sia-sia, bodoh. Sedangkan dalam King James Vers (KJV) "Vain" yang artinya bersia-sia. ${ }^{41}$ Jadi Paulus di sini menegur jemaat di Korintus supaya Injil yang mereka dengan tidak di sia-siakan, bahkan dalam terjemahan lain mengatakan jangan sampai mereka seperti orang bodoh serta Injil itu menjadi kosong atau tidak berarti karena mereka sendiri yang tidak sungguh-sungguh dalam Kristus

Kata "Kasih Karunia" dalam bahasa Yunani menggunakan kata " $\chi \alpha \rho l$ " (charis). ${ }^{42}$ Kata " $\chi \alpha \rho 1$ " (charis) khar'-ece yang artinya kasih karunia, anugerah, pemberian, kemurahan hati, senang, keramahan, syukur, pahala, faedah. ${ }^{43}$ Dengan kasus Noun feminine singular accusative. Kasus ini menunjukkan bentuk kata benda tunggal feminine. Dengan demikian kata kasih karunia merupakan bentuk kata benda tunggal, kata kasih karunia dalam (BYZ) artinya kebaikan, rahmat, kepedulian sangat ramah atau bantuan, kehendak baik.44 berarti sebagai orang percaya harus menyadari bahwa hidupnya harus memuliakan Tuhan karena semua itu anugerah Tuhan bahkan dikatakan orang percaya harus mensyukurinya dan menikmati kemurahan Allah itu dengan senang.

Jadi, frase "supaya kamu jangan membuat menjadi sia-sia kasih karunia Allah" dapat diartikan bahwa suatu larangan untuk tidak menjadikan Anugerah Allah sebagai sesuatu yang kosong atau yang sia-sia. Sedangkan dalam Firman Allah Yang Hidup (FAYH) adalah berita BIS “Karena kami bekerja bersama-sama dengan Allah, maka kami

\footnotetext{
${ }^{39}$ Hasan Sutanto, Perjanjian Baru Interlinear Yunani-Indonesia dan Konkordansi Perjanjian Baru Jilid I (Jakarta:Lembaga Alkitab Indonesia, 2010), 972.

${ }^{40}$ Hasan Sutanto, Perjanjian Baru Interlinear Yunani-Indonesia dan Konkordansi Perjanjian Baru Jilid II (Jakarta:Lembaga Alkitab Indonesia, 2010), 444.

${ }^{41}$ Bible Word, 2 Oktober 2019.

${ }^{42}$ Hasan Sutanto, Perjanjian Baru Interlinear Yunani-Indonesia dan Korkondansi Perjanjian Baru Jilid I (Jakarta:Lembaga Alkitab Indonesia, 2010), 972.

${ }^{43}$ Hasan Susanto, Perjanjian Baru Interlinear Yunani-Indonesia dan Korkondansi Perjanjian Baru Jilid II (Jakarta:Lembaga Alkitab Indonesia, 2010), 809.

${ }^{44}$ Bible Work, 2 Oktober 2019.
} 
mohon dengan sangat janganlah kalian menyia-nyiakan kebaikan hati Allah itu. Jadi, Allah sudah banyak menunjukkan kebaikan hati-Nya kepada kamu, janganlah kamu dengan siasia menerima kebaikan hati-Nya. Jadi, dalam terjemahan lain kata sia-sia, itu hal yang sama. Berarti kata sia-sia penting bagi orang percaya untuk memuliakan Tuhan. Karena orang percaya sudah menerima anugerah lewat kebaikan hati Tuhan.

\section{Menghargai Waktu (ay 2)}

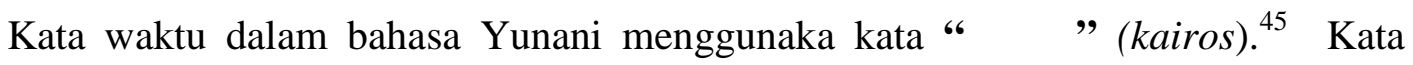
“каıро " (kairos) kahee-ros' yang artinya waktu, zaman, saat, waktu yang tepat, musim kesempatan. ${ }^{46}$ Dengan kasus noun masculine singular dative. Kata ini menunjukkan kata benda maskulin tunggal umum. Dalam King james Vers (KJV) “time” artinya waktu. Sedangkan dalam perbandingan versi FAYH mengatakan bahwa "Sebab Allah berfirman, "Jeritanmu datang kepada-Ku pada saat yang baik. ${ }^{47}$ BIS mengatakan bahwa Dalam Alkitab, Allah berkata, "Pada waktu yang diperkenankan, Aku sudah mendengarkan engkau, dan pada hari keselamatan, Aku telah menolong engkau." Ingatlah baik-baik, sekarang inilah waktu yang diperkenankan itu. Sekarang inilah hari untuk diselamatkan. Henry mengatakan:

Sekarang adalah waktu perkenanan itu, sekarang adalah hari penyelamat itu (ayat 2). Hari Injil adalah suatu hari penyelamatan, sarana kasih karunia adalah sarana keselamatan, tawaran Injil adalah tawaran keselamatan, dan sekarang inilah satu-satunya saat yang tepat untuk menerima semua tawaran ini. Hari ini, selama masih bisa disebut hari ini. Hari esok bukan urusan kita. Kita tidak tahu apa yang akan terjadi besok, atau di mana kita akan ada. Kita juga harus ingat bahwa musim kasih karunia yang ada sekarang ini waktunya singkat dan tidak pasti, dan tidak di ketahui kapan berakhirnya. Karena itu, tugas dan kepentingan kitalah untuk memanfaatkannya, selama musim itu masih berlangsung. Keselamatan kita sendiri bergantung pada apakah kita melakukannya atau tidak. $^{48}$

\footnotetext{
${ }^{45}$ Hasan Sutanto, Perjanjian Baru Interlinear Yunani-Indonesia dan Konkordansi Perjanjian Baru Jilid I (Jakarta:Lembaga Alkitab Indonesia, 2010), 972.

${ }^{46}$ Hasan Sutanto, Perjanjian Baru Interlinear Yunani-Indonesia dan Konkordandi Perjanjian Baru Jilid II (Jakarta:Lembaga Alkitab Indonesia, 2010), 419.

${ }^{47}$ Sabda, 16 September 2019

${ }^{48}$ Matthew Henry, Surat Roma, $1 \& 2$ Korintus, (Surabaya: Momentum, 2015), 894
} 


\section{Melayani Sebagai Pelayan Allah ( ayat 4-10)}

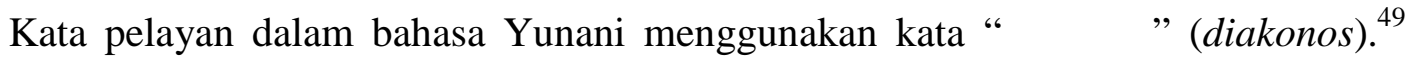
Kata "סıккоvo" (diakonos) yang artinya pelayan, pembantu, diaken ${ }^{50}$. Dengan kasus noun masculine plural nominative. Kata ini menunjukkan kata benda maskulin jamak. Dalam perbandingan Versi BIS sebaliknya, dalam segala hal, kami menunjukkan bahwa kami adalah hamba-hamba Allah. Sebab, segala macam kesukaran sudah kami derita dengan sabar. ${ }^{51}$ Dalam FAYH mengatakan sebenarnya, apapun yang kami lakukan, kami berusaha membuktikan bahwa kami benar-benar peyanan Allah. ${ }^{52}$ Dalam tafsiran Alkitab mengatakan karena Paulus dan kawan-kawannya adalah pelayan Allah, mereka sanggup membuat hidup mereka menjadi contoh untuk diteladani. Cara lain menerjemahkan adalah karena kami ini pelayan-pelayan Allah, kami malahan membuat hidup kami menjadi contoh untuk diteladani. ${ }^{53}$ Henry mengatakan:

Orang percaya melihat bahwa setiap ada kesempatan Rasul Paulus selalu menekankan bahwa orang percaya harus setia di dalam pekerjaan orang percaya, karena sering kali keberhasilan orang percaya bergantung pada hal tersebut. Matanya tertuju pada satu arah dan hatinya lurus di dalam semua pelayanannya. Kerinduannya yang terutama adalah untuk menjadi hamba Allah, dan membuktikan dirinya memang demikian. Perhatikan, para pelayan Injil harus memandang diri mereka sebagai pelayan atau hamba Allah, dan di dalam segala hal bertindak sesuai dengan kedudukan mereka tersebut. Begitulah yang dilakukan Rasul Paulus. ${ }^{54}$

\section{KAJIAN TEOLOGIS PELAYANAN PENYEBARAN INJIL}

Dalam kajian teologis ini memaparkan pelayanan penyebaran Injil itu sebagai wujud pelayanan Rasul Paulus.

\section{Kasih Karunia Allah Menyelamatkan}

Karunia mempunyai arti lebih dari sekedar kebaikan yang tidak layak kita terima. Seringkali dalam firman Tuhan, kasih karunia berarti pemberdayaan atau kuasa ilahi. ${ }^{55}$

\footnotetext{
${ }^{49}$ Hasan Sutanto, Perjanjian Baru Interlinear Yunani-Indonesia dan Konkordansi Perjanjian Baru Jilid I (Jakarta:Lembaga Alkitab Indonesia, 2010), 972.

${ }^{50}$ Hasan Sutanto, Perjanjian Baru Interlinear Yunani-Indonesia dan Konkordansi Perjanjian Baru Jilid II (Jakarta:Lembaga Alkitab Indonesia, 2010), 197.

${ }^{51}$ Sabda, jumaat 4 oktober 2019.

${ }^{52}$ Marathon, Perjanjian Baru (Kalam Hidup, 1975), 271

${ }^{53}$ M. K. Sembiring, Surat Paulus Yang Kedua Kepada Jemaat di Korintus ( Jakarta: LAI, 2013), 128.

${ }^{54}$ Ibid., 895-896.

${ }^{55}$ Paul G. Caram, Kekristenan Sejati (Jakarta:Voice Of Hope, 2004), 57.
} 
Kasih karunia adalah sesuatu yang memberdayakan kita (1 Kor. 15:10). Kasih karunia adalah sebuah zat yang Allah masukkan dalam kita sewaktu kita membutuhkannya (Ibr. 4:16). Kasih karunia adalah satu-satunya hal yang mengubah hidup kita (1 Tim. 1:13-14). Kalau Allah tidak memberi kita kasih karunia-Nya, tidak ada sesuatu pun dalam hidup kita yang akan berubah. Hanya dengan kasih karunia yang Allah berikanlah kita dimampukan untuk menjaga hati kita agar bebas dari kepahitan (Ibr. 12:15). Kasih karunia itu sangat dibutuhkan untuk mengendalikan perasaan-perasaan kita. Kasih karunia menyediakan kekuatan yang dibutuhkan untuk menaati apa yang Allah minta kita lakukan (Rm. 1:5). ${ }^{56}$ Pfitzner mengatakan:

Pada waktu itu orang-orang Korintus sudah mendengar dan menerima berita tentang kasih karunia Allah, perkenan-Nya sama sekali tidak layak mereka terima, di dalam Kristus. yang menjadi masalah adalah kemungkinan yang menguatirkan bahwa kasih karunia itu tidak dibiarkan mengubah hidup mereka. Bagi Paulus sendiri, kasih karunia tentu akan menjadi sia-sia andaikata tidak mengikuti panggilan untuk menyerahkan diri kepada kehendak Tuhan dengan menjadi rasul-rasul-Nya (1 Kor. 15:10). Kasih karunia Allah akan menjadi sia-sia bagi orang Korintus bila mereka tetap hidup untuk diri sendiri (5:15), atau bila mereka menolak untuk mendengarkan Paulus yang telah membawakan Injil kasih karunia kepada mereka. ${ }^{57}$

Dalam Wycliffe menyia-Nyiakan dalam kata sia-sia. Teman-teman sekerja merupakan terjemahan dari sunergeo (sebuah kata kerja yang di bagian Perjanjian Baru lainnya hanya dipakai dalam Mrk. 16:20; Rm. 8:28; I Kor. 16:16; Yak. 2:22). Terdapat "kerja sama" sejati sesudah keselamatan (Flp. 2:12-13). Kata sia-sia. Bandingkan Galatia 2:2; Filipi 2:16; I Tesalonika 3:5. Paulus selalu mencari bukti-bukti nyata dari kuasa Injil di antara orang-orang yang dimenangkan olehnya (I Tes. 2:13). ${ }^{58}$

Dikatakan juga kasih karunia mewarnai ajaran Yesus dalam PB. Manusia berdosa tidak mungkin bebas kutuk dosa dari usahanya sendiri, hanya karena kasih karunia Yesus manusia bisa selamat. "mereka yang hidup dalam daging, tidak mungkin berkenan kepada Allah" (Rm. 8:8). Yesus datang ke dunia dan mati di salib, untuk mengampuni dosa manusia bagi yang mau percaya dan bertobat, maka nubuat "Etika Taman Eden" menjadi "tergenapi". ${ }^{59}$ Dalam Perjanjian Baru, istilah anugerah dijelaskan dengan bahasa Yunani kharis, khairen, yang artinya "bersukacita, penampilan yang menyenangkan, disetujui, dan

\footnotetext{
${ }^{56}$ Paul G. Caram, Kekristenan Sejati (Jakarta:Voice Of Hope, 2004), 52.

${ }^{57}$ V. C. Pfitzner, Ulasan Atas Surat 2 Korintus Kekuatan Dalam Kelemahan (Jakarta:BPK Gunung Mulia, 2011), 92.

${ }^{58}$ Tim Moody Bible Institute Of Chicago, The Wycliffe Bible Commentary (Malang:Gandum Mas, 2001), 682 .

${ }^{59}$ Karel Sosipater, Etika Perjanjian Baru, (Jakarta:Suara Harapan Bangsa, 2010), 154.
} 
diterima" (Lukas 4:22; Kolose 4:6). Anugerah juga dapat berarti maksud atau kehendak baik (Lukas 1:30; 2:40,52: KPR 2:47;7:46;24:27); atau sukacita yang dilimpahkan oleh TUHAN (II Korintus 9:8. Arti lain dari anugerah ialah rasa syukur atau pengucapan syukur (Lukas 4:22; I Korintus 10:38; 15:57; II Korintus 2:14; 8:16; I Timotius 1:12). ${ }^{60}$ Karena kasih karunia-Nya Ia telah memilih umat perjanjian-Nya. Pemilihan Allah terhadap umatNya itu bukan maksud

\section{Penyelamat Telah Tiba}

Istilah keselamatan atau soteriologi yang digunakan disini berasal dari kata soteria atau soterios dan logi atau logy (salubrious salus, salutis- Latin); istilah mana secara umum dapat disebut "ilmu tentang keselamatan". Istilah soteria berakar dari kata bahasa Yunani, saos, yang kata dasarnya ialah sazo, yang memiliki arti yang dalam, yang dapat berarti “dilepaskan, dilindungi dari bahaya" (Kisah Para Rasul 7:25; 27:31; Ibrani 11:7). ${ }^{61}$ Istilah "keselamatan" adalah terjemahan dalam bahsa Yunani "soteria". Membahas tentang keselamatan tidak lepas dari kasus dalam tanam Eden, yang mengakibatkan manusia jatuh dalam dosa, dan memerlukan pertolongan dari ketidak-berdayaannya menuju kematian kekal, yaitu "penyelamatan" yang menyelamatkan manusia dari hukuman neraka selamanya. Allah dalam Taman Eden, "berprakarsa" untuk mencarikan jalan pertolongan dengan mencanangkan nubuat-Nya tentang "penebusan dosa", yang pertama dalam awal sejarah. Penebusan dosa adalah upaya menyelamatkan terhadap manusia berdosa. Di mana Bapa "merancang" penyelamatan, Anak yang "melaksanakannya", dan Roh Kudus yang "menerapkan" atau mewujudkan keselamatan itu menjadi "nyata" pada diri seseorang. "pusat penyelamatan" itu adalah salib Kristus (Rm. 1:16; I Kor. 1:18). ${ }^{62}$ Daun menjelaskan:

Seluruh umat manusia, menginginkan, merindukan keselamatan. Sebab itu mereka berusaha mencari dan mendapatkan keselamatan itu. Pada umumnya keselamatan di luar Kristus dicapai dengan bersandar pada kemampuan diri sendiri, yaitu dengan jalan berbuat baik, berbuat amal dan sebagainya. Alkitab dengan jelas mengungkapkan perbuatan baik manusia di hadapan Allah bagaikan orang yang memakai pakaian compang-camping saja. Dengan kata lain, manusia tidak mungkin bersandar kemampuan diri untuk mendapat perkenaan dari Allah. Hal ini bagaikan Adam dan Hawa yang jatuh kedalam dosa dan berusahan dengan cara sendiri membuat pakaian dari daun-daunan untuk menutupi

\footnotetext{
${ }^{60}$ Ibid., 127.

${ }^{61}$ Yakob Tomatala, Yesus Kristus Juruslamat Dunia (Jakarta:Leadership Foundation, 2004), 121.

62 Sosipater, Etika Perjanjian Baru, 155
} 
malunya, tetapi mereka gagal! Karena daun yang sebentar saja menjadi layu dan kering, tidak mungkin dapat menutup malu mereka. setelah Tuhan turun tangan menyediakan pakaian dari kulit binatang barulah secara permanen, mereka dapat menutupi malunya. ${ }^{63}$

\section{Melayani Sebagai Hamba}

Sabdono berpendapat bagaimana hati seorang hamba. Ciri seorang pelayan Tuhan yang benar, pertama: bekerja sepenuh hati bagi Tuannya. Tuan disini adalah Tuhan sendiri. Ini adalah sebuah kehidupan yang dihargai Allah, dan sungguh-sungguh berharga. Kehidupan semacam inilah yang sudah ditemukan oleh rasul Paulus (Flp. 1:21; 2 Kor. 5:14-15; 1Kor. 6:19). Seorang yang hidup bagi Tuhan, bagai prajurit yang baik tidak memusingkan penghidupannya sendiri (2 Tim. 2:4). ${ }^{64}$ Yu Kwong mengatakan:

Setiap umat Kristen mempunyai gereja sendiri dan juga mengambil bagian dalam pelayanan. Setiap pelayanan yang diperuntukan bagi Allah adalah pelayanan ya indah di mata Tuhan. Hamba-hamba Tuhan yang setia, di antaranya Paulus. Ia mengasihi bukan hanya satu gereja, tetapi semuanya. Di dalam Perjanjian Baru, minimal sebanyak sepuluh kali menyebut istilah "gereja-gereja" atau jemaat-jemaat dan yang paling banyak menyebutnya adalah surat kiriman kepada jemaat Korintus. Paulus menyinggung dengan istilah tersebut karena di dalam tubuh gereja di korintus terjadi perpecahan; anggotanya hanya memikirkan diri sendiri dan tidak menghiraukan anggota tubuh lainnya, Oleh karena Paulus secara khusus mengajarkan tentang kebenaran ini. Oleh karena Tuhan mengasihi gereja-Nya, bagi manusia yang melayani di gereja sudah pasti pelayanan orang percaya diperkenankan Tuhan. ${ }^{65}$ Ginting mengatakan bahwa:

Hamba Tuhan yang terbesar adalah Hamba Tuhan yang menjadi pelayan bagi umat Tuhan. Bila di dunia memimpin dilayani, di dalam gereja, pemimpin adalah yang melayani dan rela menjadi hamba Tuhan bagi yang lain. Oleh karena itu, seorang memimpin gereja adalah seorang pelayan gereja dan bukan tuan gereja yang harus dilayani. ${ }^{66}$

Penulis menyimpulkan bahwa seorang pelayan Allah harus memiliki hati yang baik untuk melayani Tuhan di gereja manapun, karena seorang pelayan harus mengasihi jemaat tersebut.

Rasul Paulus menasihatkan jemaat di Korintus supaya Injil yang mereka dengar tidak di sia-siakan, bahkan jangan sampai mereka seperti orang bodoh serta Injil itu menjadi kosong atau tidak berarti karena mereka sendiri yang tidak sungguh-sungguh

\footnotetext{
${ }^{63}$ Paulus Daun, Jemaat Kolose Yang Bertumbuh (Manado:Yayasan Daun Family, 2008), 7-8

${ }^{64}$ Erastus Sabdono, Pelayanan Yang Sesungguhnya, (Jakarta:REHOBOT, 2017), 58.

${ }^{65}$ Hsueh Yu Kwong, Sepatah Kata Untuk Hamba Tuhan (Manado:Yayasan Daun Family, 2009), 226.

${ }^{66}$ Edi Suranta Ginting, Hamba Tuhan Pelayan Gereja, (Bandung: Kalam Hidup, 2014), 120.
} 
dalam Kristus. Berarti sebagai orang percaya harus menyadari bahwa hidupnya harus memuliakan Tuhan karena semua itu anugerah Tuhan bahkan dikatakan orang percaya harus mensyukurinya dan menikmati kemurahan Allah itu dengan senang. Orang percaya harus menghargai kesempatan yang di berikan Tuhan untuk Melaksana Tugas Amanat Agung-Nya, kepada orang yang belum mengenal Tuhan Yesus dalam dirinya. Karena memberitakan Injil adalah perintah Tuhan Yesus. Tetapi dalam memberitakan Kabar Anugerah, tidak harus hanya ditujukan terhadap orang yang bukan Kristen saja; tetapi juga terhadap orang Kristen KTP (Kristen Tanpa Pertobatan), atau mereka sekedar beragama Kristen karena faktor keluarga, namun mereka belum mengenal Yesus Kristus dan anugerah-Nya secara pribadi dan benar. Seorang pelayan harus memiliki ciri rendah hati untuk memberitakan kabar keselamatan kepada semua orang, karena keselamatan hanya ada di dalam Kristus Yesus.

\section{IMPLIKASI PERSPEKTIF PELAYANAN PENYEBARAN INJIL}

Berdasarkan hasil analisa eksegetikal dan teologis ada 3 Perspektif Rasul Paulus Tentang Pelayanan Penyebaran Injil yaitu: tidak menyia-nyiakan kasih karunia Allah, menghargai waktu dan melayani sebagai Pelayan Allah

\section{Tidak Menyia-Nyiakan Kasih Karunia Allah}

Rasul Paulus menjelaskan dalam 2 Korintus 6:1c bahwa supaya kamu jangan membuat menjadi sia-sia kasih karunia Allah, yang telah kamu terima. Bahwa Rasul Paulus menasihatkan jemaat di Korintus supaya Injil yang mereka dengarkan tidak menjadi sia-sia, karena mereka sendiri yang tidak sungguh-sungguh didalam Kristus untuk memberitakan Injil. Bahkan kasih karunia Allah sudah banyak menunjukkan kebaikan hati-Nya kepada jemaat di Korintus supaya janganlah di sia-siakan menerima kebaikan hati-Nya. Jadi, kata sia-sia, itu hal yang sama. Berarti kata sia-sia penting bagi orang percaya untuk memuliakan Tuhan. Karena orang percaya sudah menerima anugerah lewat kebaikan hati Tuhan.

Karunia mempunyai arti lebih dari sekedar kebaikan yang tidak layak orang percaya terima. Seringkali dalam firman Tuhan, kasih karunia berarti pemberdayaan atau kuasa ilahi. Kasih karunia adalah sesuatu yang memberdayakan kita (1 Kor. 15:10). Kasih karunia adalah sebuah zat yang Allah masukkan dalam kita sewaktu kita membutuhkannya (Ibr. 4:16). Kasih karunia adalah satu-satunya hal yang mengubah hidup orang percaya (1 Tim. 1:13-14). Kalau Allah tidak memberi kita kasih karunia-Nya, tidak ada sesuatu pun dalam hidup kita yang akan berubah. Hanya dengan kasih karunia yang Allah berikanlah 
kita dimampukan untuk menjaga hati orang percaya agar bebas dari kepahitan (Ibr. 12:15). Kasih karunia itu sangat dibutuhkan untuk mengendalikan perasaan-perasaan kita. Kasih karunia menyediakan kekuatan yang dibutuhkan untuk menaati apa yang Allah minta kita lakukan (Rm. 1:5).

\section{Menghargai Waktu}

Dalam 2 Korintus 6:2 di jelaskan bahwa Sekarang adalah waktu perkenanan itu, sekarang adalah hari penyelamat itu (ayat 2). Hari Injil adalah suatu hari penyelamatan, sarana kasih karunia adalah sarana keselamatan, tawaran Injil adalah tawaran keselamatan, dan sekarang inilah satu-satunya saat yang tepat untuk menerima semua tawaran ini. Hari ini, selama masih bisa disebut hari ini. Hari esok bukan urusan orang percaya. Orang percaya tidak tahu apa yang akan terjadi besok, atau di mana orang percaya akan ada. Orang percaya juga harus ingat bahwa musim kasih karunia yang ada sekarang ini waktunya singkat dan tidak pasti, dan tidak di ketahui kapan berakhirnya. Karena itu, tugas dan kepentingan orang percayalah untuk memanfaatkannya, selama musim itu masih berlangsung. Keselamatan kita sendiri bergantung pada apakah orang percaya melakukannya atau tidak.

\section{Melayani Sebagai Pelayan Allah}

Dalam 2 Korintus 6:4-10 menjelaskan bahwa dalam pelayan Allah adalah harus menahan berbagai hal yaitu: kesabaran dalam penderitaan, kesesakan dan kesukaran, dalam menanggung dera, dalam jerih payah, dalam berjaga-jaga dan berpuasa, dalam sukacita dan dukacita dalam menghadapi pelayanan Tuhan. Apapun yang terjadi harus melayani dengan segenap hati, untuk memberitakan Injil Tuhan.

Orang percaya melihat bahwa setiap ada kesempatan Rasul Paulus selalu menekankan bahwa orang percaya harus setia di dalam pekerjaan Tuhan, karena sering kali keberhasilan orang percaya bergantung pada hal tersebut. Matanya tertuju pada satu arah dan hatinya lurus di dalam semua pelayanannya. Kerinduannya yang terutama adalah untuk menjadi hamba Allah, dan membuktikan dirinya memang demikian. Perhatikan, para pelayan Injil harus memandang diri mereka sebagai pelayan atau hamba Allah, dan di dalam segala hal bertindak sesuai dengan kedudukan mereka tersebut. Begitulah yang dilakukan Rasul Paulus.

\section{PENUTUP}

Secara keseluruhan pokok pembahasan pelayanan penyebaran Injil itu adalah hal yang baik, karena itu menunjukkan bahwa orang percaya menjangkau jiwa-jiwa yang belum mengenal Kristus, maka perlu pelayanan penyebaran Injil. Dalam Surat 2 Korintus 
6:1-10, Rasul Paulus menasihatkan jemaat di Korintus supaya mereka mengerti Injil itu. Sehingga mereka tidak menyia-nyiakan kasih karunia Allah yang mereka terima, karena anugerah yang diberikan Tuhan kepada orang percaya hanya lewat pengorbanan-Nya untuk menebus dosa umatnya.

Menjalankan dan melakukan pelayanan penyebaran Injil itu bukanlah sesuatu yang mudah untuk disampaikan. Karena ada banyak tantangan yang datang dalam melaksanakan tugas pelayanan untuk penyebaran Injil itu. Oleh karena itu seorang hamba Tuhan yang memberitakan Injil harus melibatkan Tuhan agar kasih karunia Allah, tidak disia-siakan begitu saja. Karena rasul Paulus memberitakan Injil yang luar biasa, dan rasul Paulus juga menghargai waktu dalam pelayanan penyebaran Injil. Walaupun banyak tantangan dan ritangan akan tetapi Tuhan selalu memampukan rasul Paulus agar kuat, teguh dan setia melayani untuk memberitakan kabar baik sekali pun ia pertaruhannya nyawannya untuk memenangkan jiwa-jiwa.

Manusia jatuh ke dalam dosa karena ketidaktaan, oleh karena kasih karunia Allah kepada manusia diselamatkan dari belenggu dosa. Seorang pelayan Tuhan harus memiliki hati sebagai hamba yang melayani Tuhan dengan segenap hati. Soli Deo Gloria 


\section{DAFTAR PUSTAKA}

Ambarita, D. (2018). Perspektif Misi Dalam Perjanjian Lama Dan Perjanjian Baru. Medan: Pelita Kebenaran.

Arikunta, S. (2002). Prosedur Penelitian: Suatu Pendekatan Praktek. Jakarta: Rineka Cipta \& PT Asdi Mahastya.

B.J, B. (1992). Intisari Iman Kristen. Jakarta: BPK Gunung Mulia.

Beownllee, M. (2011). Tugas Manusia Dalam Dunia Milik Tuhan. Jakarta: BPK Gunung Mulia.

Bergant, D. (2002). Tafsir Alkitab Perjanjian Baru. Yogyakarta: Kanisius.

Beyer, U. (2008). Memberi Dengan Sukacita. Jakarta: BPK Gunung Mulia.

Browning, W. (2011). Kamus Alkitab. Jakarta: BPK Gunung Mulia.

Caram, P. G. (2004). Kekristenan Sejati. Jakarta: Voice of Hope.

Champion, D. J. (1999). Metode Dan Masalah Penelitian Sosial. Bandung: Rafika Aditama.

Chandra, B. (1995). Pengantar Statustuk Kesehatan. Jakarta: Buku Kedokteran IGD.

Darmaputra, E. (2010). Menyembah Dalam Roh Dan Kebenaran. Jakarta: BPK Gunung Mulia.

Daun, P. (2008). Jemaat Kolose Yang Bertumbuh. Manado: Yayasan Daun Family.

Daun, P. (2015). Misiologi Dalam Perspketif Historikal \& Doktrinal. Jakarta: Seving In Missiong.

Drane, J. (2005). Memahami Perjanjian Baru. Jakarta: BPK Gunung Mulia.

End, T. V. (2008). Tafsiran Alkitab Surat Roma. Jakarta: BPK Gunung Mulia’.

F, D. W. (2004). Injil Dan Marapu. Jakarta: BPK Gunung Mulia.

Ginting, E. S. (2014). Hamba Tuhan Pelayan Gereja. Bandung: Kalam Hidup.

Graham, B. (1992). Beritakan Injil. Bandung: Literatur Baptis.

Guthrie, D. (2009). Pengantar Perjanjian Baru Volume 2. Surabaya: Momentum.

Hadiwijono, H. (2006). Kebatinan Dan Injil. Jakarta: BPK Gunung Mulia.

Hakh, S. B. (2010). Perjanjian Baru Sejarah Pengantar Dan Pokok-Pokok Teologisnya. Bandung: Bina Media Informasi. 
Harinaldi. (2009). Prinsip-Prinsip Statsistik Untuk Teknik Dan Sains. Jakarta: Erlangga.

Haryono, D. (2012). Kamus Besar Bahasa Indonesia. Jakarta: Media Pustaka Phoenix.

Heath, W. S. (1966). Penginjilan Dan Pelayanan Pribadi. Surabaya: Yakin.

Henry, M. (2015). Surat Roma, $1 \& 2$ Korintus. Surabaya: Momentum.

Hwang, T. (2016). Apa Tujuan Dari Penciptaan. Korea: Sarah Hae-Ok Cho.

Kee, H. C. (2011). Alkitab Edisi Studi. Jakarta: LAI.

Klapwijk, J. (2015). Perjanjian Baru. Jakarta: YKBK.

Kwong, H. Y. (2009). Sepatah Kata Untuk Hamba Tuhan. Manado: Yayasan Daun Family.

Manase Gulo, dkk. (2012). Katalog 2009 - 2014 Sekolah Tinggi Teologi Arastamar Bengkulu (STTAB). Bengkulu: PERMATA Rafflesia.

Mangentang, M. (2005). Visi Dan Misi Setia. Jakarta: Delima.

Martin, A. (2002). Kamus Besar Bahasa Indonesia. Surabaya: Karina.

Moalusi, E. (1977). Penyelidikan Perjanjian Baru. Bandung: Kalm Hidup.

Nasution, M. E. (2006). Proses Penelitian Kuantitatif. Jakarta: Fakultas Ekonomi Universitas Indonesia.

Nazir, M. (2003). Metode Penelitian. Jakarta: Gratia Indonesia.

Ningrat, K. (1997). Methodologi Penelitian Masyarakat. Jakarta: Gramedia.

Pfeiffer, C. F. (2001). Tafsiran Alkitab Wycliffe. Malang: Gandum Mas.

Pfitzner, V. (2008). Ulasan Atas Surat 2 Korintus Kekuatan Dalam Kelemahan. Jakarta: BPK Gunung Mulia.

Pito, B. (2012). Prinsip Kepemimpinan Paulus Dalam Roma 12:6-8 Dan Implikasinya Bagi Mahasiswa Sekolah Tinggi Teologi Arastamar Bengkulu (STTAB). Bengkulu.

Sabdono, E. (2017). Pelayanan Yang Sesungguhnya. Jakarta: Rehobot.

Sembiring, M. (2013). Surat Paulus Yang Kedua Kepada Jemaat Di Korintus. Jakarta: LAI.

Sosipater, K. (2010). Etika Perjanjian Baru. Jakarta: Suara Harapan Bangsa.

Surbakti, E. (2008). Benarkah Injil Kabar Baik. Jakarta: BPK Gunung Mulia.

Sustanto, H. (2010). Perjanjian Baru Interlinear Yunani-Indonesia dan Korkondansi Perjanjian Baru Jilid I. Jakarta: LAI. 
(2010). Perjanjian Baru Interlinear Yunani - Indonesia Dan Konkordansi Perjanjian Baru Jilid II. Jakarta: LAI.

Tenney, M. C. (2009). Survei Perjanjian Lama. Malang: Gandum Mas.

Tim Penyusun STATUTA. (2014). Statuta Sekolah Tinggi Teologi Arastamar Bengkulu (STTAB) Bengkulu. Bengkulu: Permata Rafflesia.

Tomatala, Y. (2002). Penginjilan Masa Kini. Malang: Gandum Mas.

Tomatala, Y. (2004). Yesus Kristus Juruselamat Dunia. Surabaya: Leadership Foundation.

Tong, S. (2004). Roh Kudus, Doa Dan Kebangunan. Surabaya: Momentum.

Tong, S. (2013). Theologi Penginjilan. Surabaya: Momentum.

Wagner, C. P. (1991). Manfaat Karunia Roh Untuk Pertumbuhan Gereja. Malang: Gandum Mas.

Wellem, F. (2005). Hidup Bagi Kristus. Jakarta: BPK Gunung Mulia. 